\title{
Interaction for Unity among Trainee Teachers at Selected Teacher Training Institutes in East Malaysia
}

\author{
Abdul Razaq Ahmad, Najamuddin Hj. Bachora*
}

\begin{abstract}
The purpose of this study was to identify the level of tendency for interaction among trainee teachers at the Malaysian Institutes of Teacher Education (ITE) in the states of Sabah and Sarawak. The study also examined demographic predictors of interaction levels and considered how interaction takes place in different environments at the institutes among students of different ethnicities. Special attention was given to how trainee teachers interact while they participate in curricular and co-curricular activities, in the residential colleges and during their daily activities as well as online. Demographic factors included level of study, ethnicity and religion. The sample consisted of 299 third semester foundation Bachelor of Education students (PPISMP) and final year Bachelor of Education students (PISMP). A self constructed questionnaire based on extensive literature review was used for data collection. Desriptive analysis revealed that the overall level of tendency for interaction among students of various ethnic groups was high. The highest was interaction in the co-curricular environment, followed by interaction in daily activities, interaction in the residential colleges, and interaction in curricular activities. The level of appreciation of unity among the students of various ethnic groups was high. Results also showed that relationship with peers was the strongest contributor to students' tendency for interaction with people from different ethnic backgrounds, followed by school experiences, family influence and the mass media. These results are important for teacher educators and policy makers in diverse societies like Malaysia.
\end{abstract}

Keywords: Student interaction Malaysia, diversity Malaysia, National unity, Teacher Education Malaysia,

* Faculty of Education, National University of Malaysia 


\section{Introduction}

In 1963, the Malay Peninsula, which had gained independence from British rule in 1957, was joined by Sabah and Sarawak to form the Federation of Malaysia. Established on a multiracial, multireligious foundation, questions of racial integration and unity play a major role in Malaysia. The Government has taken numerous attempts to integrate the people through political, economic and social development initiatives in order to prevent conflicts among different groups.

The education system is one of the most important and effective tools for creating a national identity, national unity, and fostering nationalism and love for the country (Shamsul Amri 2007). Education is also considered as a way to reduce ethnic and racial differences (David \& Fatima Abdul Hadi Yaacob 2006). The educational system can serve as a platform to provide knowledge about the various cultures existing in the society. Hence, understanding this matter will result in open acceptance regarding the existence of social diversity and tolerance for all forms of social order. According to Abdul Halim (2009), the education system should not only be beyond racism but should also serve as the place to strengthen, nurture and grow the values of tolerance, friendlines, cooperation, understanding and unity.

\section{Interaction and Early Socialization}

It is undeniable that interaction is the key and foundation of human life. In fact, human interaction is also the main social activity, as people are in dire need of interaction with others in every single activity of their lives. By interacting with others, people are able to express all their needs and requirements. Particularly, humans are social animals who do not like to live in isolation without friends in the neighborhood. For students, interaction with others in the learning environment is needed, including with those of different ethnic groups.

According to Najeemah and Yasmin (2010), social interaction between students of different ethnic groups usually happens if they live together in a multi-ethnic environment. This is because, in such 
circumstances, students do not have any other way but to interact with partners from other ethnic groups to continue living harmoniously on campus. given a conducive setting and infrastructure, students will have broad opportunities to mix with others from different ethnic groups. This will expedite the process of recognizing and accepting ethnic and cultural differences. In fact, campus interaction in classrooms, laboratories and other places in the campus environment will provide meaningful experiences for the students' social development (Kim \& Sax, 2007).

The tendency for students to interact in a multi-ethnic environment is somehow influenced by their early socialization prior to or before they enroll in the institutions of higher learning. According to Bronfenbrenner's ecological theory (2005), the main agents of early socialization are the family, school, peers and the mass media. These influential factors have a huge impact on students' interaction. Bronfenbrenner's theory emphasizes the influence of the environment on individual development. In this context, the environment which encourages interaction among students of the Institutes of Teachers Education, would influence their development and growth.

According to Amir Hasan Dawi (2004 and 2006), in the context of ethnic diversity, polarization among students is likely to happen due to habits that have been formed based on their different cultures. Basing his arguments on Pierre Bourdieu's view on the role of habit in different areas of life, Amir Hasan Dawi (2004) synthesised the state of habit as it exits within the individual as a result of the socialization process. Personal habits are also formed as a result of cultural acquisition in an area of life. They become cultural assets and have the power to act as socialization agents. These cultural assets influence social habits to act as personal motives. If the personal habits prior to enrolling in university are motives for unity, it is likely that the students will have a sense of unity with people of different ethnic groups (Amir Hasan Dawi 2004).

Early socialization experienced by children is very much associated with their interactions with the environment. This later influences their attitudes and behaviors. Hence, Bronfenbrenner's ecological theory is suitable to be used in studying the relationships of early socialization with students' tendency to interact with others 
at teacher training institutes. The strength of the ecological theory lies in the manner it emphasises various social environments which affect students' development, especially the aspects of the micro systems, such as family, school and peers (Sharipah Azizah, 2010).

It is undeniable that the education system is one of the most important and effective tools for creating a national identity and national unity while fostering nationalism and love for the country (Shamsul Amri 2007). Education is also considered as a way to reduce ethnic and racial differences (David \& Fatima, 2006). This is because the education system has a platform to provide knowledge about the various cultures existing in the society. Hence, understanding this matter will result in open acceptance of social diversity and promote tolerance for all forms of social order. According to Abdul Halim (2009), the education system should be beyond racism. On the contrary, it should be the place to promote, nurture and grow the values of tolerance, friendship, cooperation, understanding and unity. Developing relationships among individuals from different ethnicities is seen as a positive social action that should be practiced by the whole nation (Fatan Hamamah 2011).

In spite of Malaysia's successful economic development and the relatively good relationships among its people, there are still signs of problems, mis-understanding and lack of consensus among people of different races and religions especially regarding nation building (Abdul Rahman Embong 2007). It was reported by JPNIN (2012) that Malaysia's Community Tension Index (IKM) increased from 4.7 cases in 2011 to 4.9 cases in the third quarter of 2012. During the same period, Malaysia slightly dropped in the Global Harmony Index (GPI) from number 19 out of 153 countries in 2011 to number 20 in the third quarter of 2012. The younger generation has apparently started questioning the "social contract" which has been the core of unity and understanding between different ethnic groups (Hasnah Hussin 2007). Youth from other ethnic groups have started to question the special position of the Malays, the Malay language and the role of Islam as the official religion of Malaysia. This could lead to conflict if not handled properly (JPNIN 2006).

The education system is said to be an effective avenue for socialization and dissemination of cultural values. However, it is still unclear how it can produce huge impacts particularly in encouraging 
tolerance, reducing prejudice and diminishing discrimination against any group. According to Norliza Mohammad (2011) it is very difficult to realize unity through the education system if the system still provides basic education which emphasises on certain values of only some of the ethnic groups. Sia Keng Yek (2005) and Tan Yao Sua (2010) also said that the vernacular schools system has to be blamed as a factor that magnifies the gap between ethnic groups, which indirectly weakens national unity. Other studies on ethnic relations in the context of the education system found problems in terms of lack of interaction and polarization among the different ethnic groups (Adnan @ Nan Thu, 1992, Amir Hasan Dawi 2004a; Institute for Research on Higher Education 2004; Ministry of Education, 1984; Morsin Perman 1991; Mansor Mohd Noor 2005; Noran Fauzan et al., 1987; Norazizah Othman 2007; Norsiah Abd Rahman 2005; Nor Azman Mohamed 2010; Rosliawati Ahmad 2008; Sanusi Osman 1989) .

Most students prefer to interact with someone from their own ethnic group. This phenomenon is said to be influenced by agents of early socialization, particularly parents and family members (Faridah Karim and T. Subahan 1986, Juang and Syed 2010; Rodrigues-Garcia and Wagner 2009 ), schools (Godwin et al. 2001; Khalim Zainal et al. 2006; Quintelier 2007), peer groups (Liebkind and McAlister 1999; Seltzer and Waterman 1996) and the mass media (Chew Fong Peng 2005; Ezhar Tamam et al . 2006; Houston et al. 2003; Juliana and Mahyuddin 2009; Latiffah Pawanteh 1993). However, it is still uncertain how early socialization agents influence students at institutes of teacher education to interact with others from different ethnic backgrounds, because there are not yet any studies regarding this matter.

\section{The Present Study}

The purpose of this study was to identify the level of interaction tendency among trainees of the Institutes of Teacher Education (ITE) in Sabah and Sarawak, Malaysia. The study also examined demographic predictors of interaction levels and considered how interaction takes place in different environments at the institutes among students of different ethnicities. Special attention was given to how trainee teachers interact while they participate in curricular and co-curricular activities, at the residential colleges and during their daily activities as well as online. 
Demographic factors included students' specializations, ethnicity and religion.

\section{Method}

The instrument used in this study was a self-constructed questionnaire developed after extensive literature review. It aimed to provide insight about the trainee teachers' tendency to interact with other trainees from different ethnic groups in Sabah and Sarawak. The instrument consisted of questions on the tendency to interact in an environment such as during curricular and co-curricular activities in the residential colleges, during their daily activities and in "cyber-space". The second aspect was, the effects of early socialization, namely the influences of family, school, peers and mass media. The third aspect was appreciation of the values related to unity. Respondents were randomly selected using stratified random group sampling, from third semester foundation PPISMP students and final semester B.Ed. students. A total of 307 students were chosen from the Malaysian Institutes of Teacher Education, Sabah and Sarawak campuses. Of these, responses from only 299 respondents were used for analysis, after eliminating extreme cases (outliers) so as not to affect the results of this study (Rosseni Din 2010). Reliability analysis for all constructs generated Cronbach Alpha values between .775 and .957 confirming that the items could be used for further analysis.

\section{Findings and Discussion}

\section{Demographic bacground}

Respondents were final year students from two education programs which have the highest number of registered students. They were the semester three Bachelor of Education Foundation students (FP (B.Ed) and final semester Bachelor of Education (B. Ed). Table 1 shows the number of respondents from both programs. A total of $178(59.5 \%)$ respondents were Foundation Program students, whereas 121 students (40.5\%) were final semester B.Ed. students

Respondents came from several ethnic and religious backgrounds. The largest group of respondents were 184 (61.5\%) Muslim Malay and other Bumiputra (Natives). The Malay Muslim students were mostly from the west coast of Sabah. They were grouped 
together with other natives (Bumiputra) who had converted to Islam. The second largest group were 77 (25.8\%) non-muslim Bumiputra students, followed by $34(12.7 \%)$ Malaysia Chinese. In terms of religion, $184(61.5 \%)$ of the respondents were Muslims, 92 (30.8\%) were Christians and the remaining 23 (7.7\%) were Buddhists.

Table 1: Respondents' Background Characteristics

\begin{tabular}{|l|l|l|l|}
\hline & Aspect & Number & Percentage \\
\hline $\begin{array}{l}\text { Academic } \\
\text { Program }\end{array}$ & $\begin{array}{l}\text { PPISMP Se- } \\
\text { mester 3 }\end{array}$ & 178 & 59.5 \\
\cline { 2 - 4 } & $\begin{array}{l}\text { PISMP Se- } \\
\text { mester 8 }\end{array}$ & 121 & 40.5 \\
\hline Ethnicity & $\begin{array}{l}\text { Muslim Ma- } \\
\text { lays \& Bumi- } \\
\text { putera }\end{array}$ & 184 & 61.5 \\
\cline { 2 - 4 } & $\begin{array}{l}\text { Non-muslim } \\
\text { Bumiputera }\end{array}$ & 77 & 25.8 \\
\cline { 2 - 4 } & Chinese & 38 & 12.7 \\
\hline Religion & Islam & 184 & 61.5 \\
\hline & Christianity & 92 & 30.8 \\
\hline & Buddhism & 23 & 7.7 \\
\hline
\end{tabular}

\section{Tendency for interaction and appreciation of unity}

Desriptive analysis revealed that the overall level of tendency for interaction among students of various ethnic groups in Sabah and Sarawak IPG zones was high (mean 4.32; SD 4.472). The highest mean is for the tendency of students' interaction in the co-curricular environment (mean 4.47; SD 0.497), followed by the tendency of students interaction in the environment for daily activities (mean 4.35; SDs 0.581)), interaction environment at the residential colleges (mean 4.30; SDs 0571), and interaction in curricular activities (mean 4.27; SD 0.587). However, the lowest tendency of students' interaction is via the websites (mean 4.17; SDs is 0.628 ). The findings of students' interaction in the institutes are shown in Table 2 below; 
Table 2: Level of tendency for Interaction among students of various ethnic groups

\begin{tabular}{|l|l|l|l|}
\hline Environment & Mean & SD & $\begin{array}{l}\text { Interpretation of } \\
\text { Level }\end{array}$ \\
\hline Curricular Environment & 4.27 & 0.587 & High \\
\hline Co-curricular Environment & 4.47 & 0.497 & High \\
\hline $\begin{array}{l}\text { Environment at Resedential col- } \\
\text { leges }\end{array}$ & 4.30 & 0.571 & High \\
\hline Environment of Daily activities & 4.35 & 0.581 & High \\
\hline Websites environment & 4.17 & 0.628 & High \\
\hline Overall IPG environment & 4.32 & 0.472 & High \\
\hline
\end{tabular}

The results show that the trainee teachers who are future primary school teachers, found it quite easy to interact with their peers from different ethnic groups. This is important considering the fact that as future teachers, they will become agents of socialization in their future schools. This will help them to foster great interaction and unity among their future students. The results are consistent with results of previous studies that showed students who are living in campus with various kinds of people have a high level of interaction (Chang 1999; Gurin et al. 2002 Pike \& Kuh, 2006).

However, there are also studies that indicated that the level of students' interaction with various ethnic groups was at a moderate level and some even reported low interaction. Studies conducted by Hamidah et al. (2011), Mohd Rizal and Thay (2012), Ramlee Mustapha et al. (2009) and Rusimah et al. (2004) showed that the level of interaction among students was at a moderate level. On the other hand, a study by Abdul Razaq et al. (2010) on 335 students in the district of Temerloh, Maran and Kuantan in the Malaysian state of Pahang showed that students' awareness and acceptance of school diversity was unsatisfactory and was at a low level. Similarly, a study by Rusimah et al. (2004) on the interaction climate of the students at the Northern University of Malaysia (UUM) found that the students were more likely to mix with peers from a similar ethnic or racial background. 
This situation must be addressed by the students' affairs departments at institutions of higher learning. This is because interaction with people from different backgrounds and different life experiences will enhance one's knowledge and experience, both of which are useful after graduation, especially for people living in a multi-cultural society (Umbach \& Kuh, 2006). In fact, cross-racial interaction has been found to increase cognitive development, enhance self-academic and social capabilities (Chang 1999; Gurin et al. 2002) improve civic awareness (Chang et al. 2004) and provide meaningful experiences for students' development (Kim \& Sax, 2007).

In addition, the researchers also measured the level of appreciation of unity among the students of various ethnic groups in Sabah and Sarawak IPG zones. Findings showed a high level of appreciation of unity (mean 4.29; SD 0.421). Responses to the item 'I often speak Bahasa Melayu while interacting with friends from other ethnic groups' were mostly affirmative (mean 4.41; SD 0.561), while responses to 'I always partner with a friend of other ethnic groups in a program at the campus' were mostly negative (mean $4.19 ; 0.786$ ). A summary of the items is shown in table 3 below;

Table 3: Unity appreciation among students of various ethnic groups

\begin{tabular}{|l|l|l|}
\hline Statement / Item & Mean & SD \\
\hline $\begin{array}{l}\text { I am proud of the excellent results achieved by } \\
\text { students of other ethnic groups }\end{array}$ & 4.28 & 0.685 \\
\hline $\begin{array}{l}\text { I always use Malay language when I interact } \\
\text { with friends of other ethnic groups }\end{array}$ & 4.41 & 0.561 \\
\hline $\begin{array}{l}\text { I can accept the lifestyle practiced by my } \\
\text { friends of other ethnic groups }\end{array}$ & 4.26 & 0.771 \\
\hline $\begin{array}{l}\text { I always cooperate with friends of other ethnic } \\
\text { groups when taking part in any programs } \\
\text { organised by the campus }\end{array}$ & 4.19 & 0.786 \\
\hline $\begin{array}{l}\text { I do not have any prejudice towards friends of } \\
\text { other ethnic groups }\end{array}$ & 4.33 & 0.620 \\
\hline Overall mean & 4.29 & 0.421 \\
\hline
\end{tabular}


The findings in Table 3 indicate that students who are exposed to diversity on campus, especially to interaction with peers from different ethnic backgrounds, received positive effects and could go on to influence the community, especially in fostering racial unity (Gurin et al., 2002). In fact, according to Najeemah and Yasmin (2010), when a close pattern of social interaction is formed between the ethnic groups, it will strengthen unity and understanding among the people in the country. Therefore, this study shows that appreciation of unity among students is high. This is a good thing since they are future agents of socialization when they are in school later. It is hoped that as future teachers, they will be able to cultivate the seeds of unity among students at schools, since they already have the values of unity embedded in them. In fact, when unity is strongly formed, it will guarantee stability, thereby moving the country towards progress and higher achievement (Aizat Khairi 2011). Education plays a key role in disseminating and sharing values and aspirations when individuals from different socio-economic backgrounds, religions and ethnicities interact, understand and accept their differences. Shared values and experiences will further strengthen unity and form a national identity (MOE 2012).

\section{Contribution of early socialization factors}

To identify the strength of the relationship between the effects of early socialization with students' tendency to interact and their appreciation of the values for unity, Structural Equation Modeling (SEM) analysis was used. Before testing the structural model, CFA was conducted to determine the soundness of the constructs. The structural model had adequate fit, with all the incremental indices, such as TLI and CFI, being above.90. The fitness indices for the structural model were as follows: CMIN/DF (1.395), TLI ( .953), CFI ( .957) and RMSEA ( .032). The findings are as shown in Figure 1.

Figure 1 shows that relationship with peers was the strongest contributor to students' tendency for interaction with people from different ethnic backgrounds (.50), followed by school experiences (.29), family influence (.18) and the mass media (.17). Table 4 shows the path coefficients of the influence of family, school, peers and mass media on the tendency to interact and to appreciate the values of unity among students of various ethnic groups. 


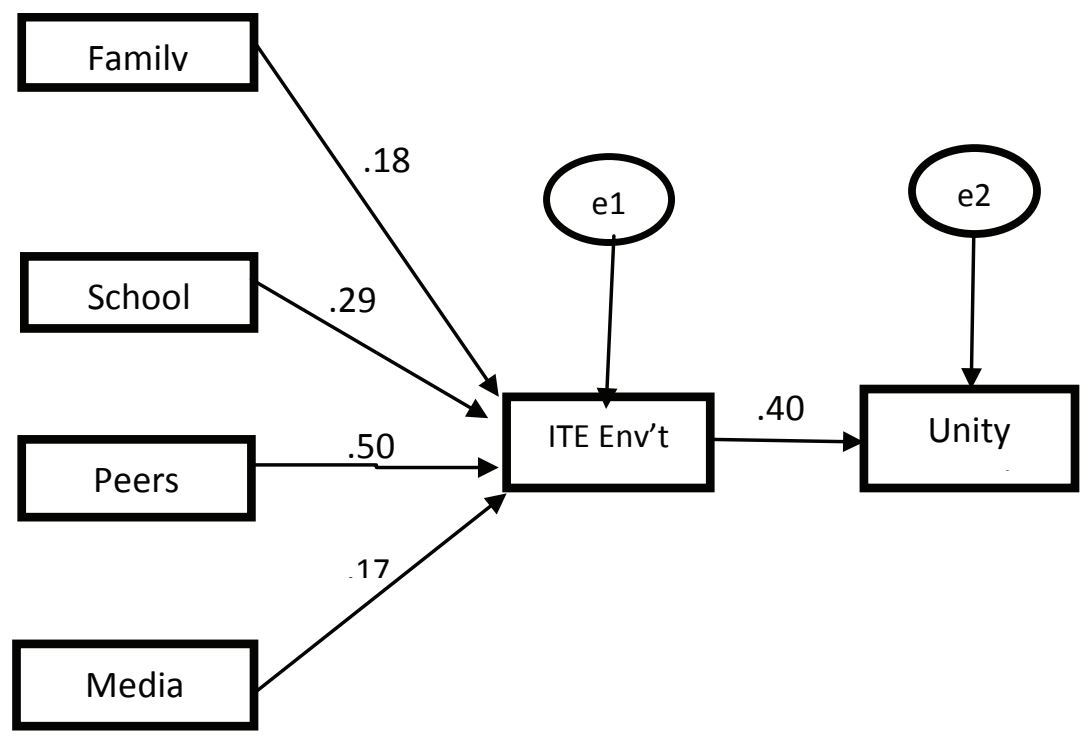

Figure 1: Structural model of the effects of Early Socialization

Based on Table 4 peer influence had the strongest influence on the tendency to interact $(C . R=8.712, \beta=0.504)$. This was followed by school socialization $(\beta=0.288, C . R=5.441)$, family $(\beta=0.183, C . R=$ 3.407), and mass media $(\beta=0.173, C . R=3.283)$. Meanwhile, the tendency to interact did not have any influence on appreciation of unity $(\beta=0.073, C . R=1.498$ and $P=0.134)$.

Table 4: Path coefficients between variables

\begin{tabular}{|l|l|l|l|}
\hline Relations of Variables & Beta & P & $\begin{array}{l}\text { Critical } \\
\text { Ratio }\end{array}$ \\
\hline Environment <--- influenced by family & 0.183 & $* * *$ & 3.407 \\
\hline Environment<--- influenced by school & 0.288 & $* * *$ & 5.441 \\
\hline Environment<--- influenced by peers & 0.504 & $* * *$ & 8.712 \\
\hline Environment<--- influenced by media & 0.173 & 0.001 & 3.283 \\
\hline Unity Appreciation<--- Environment & 0.073 & 0.134 & 1.498 \\
\hline
\end{tabular}


This means that early socialization has a positive impact on the tendency for students to interact with peers from other ethnic groups. If the effect of early socialization is strong, the influence on the tendency is relatively high. Continuous exposure by early socialization agents such as family, school, peers and the mass media about the importance of interaction with individuals from different ethnics will influence the students' perceptions and behaviors towards people from different ethnic groups.

The results showed that peers have a strong influence on the tendency to interact among students of various ethnic groups in the IPG, followed by other influences from the school, family and mass media. In fact, the impact of peer influence is also expected to foster racial unity. According to Irwan Fariza (2012), peers are very influential in terms of disseminating values, attitudes and outlook on life. In fact, friends are the most influential agent in the socialization process because they spend much of their time with their friends in and outside school. Findings of the study also showed that students' participation in sports and recreational activities also helps to foster unity.

These findings are consistent with previous studies on socialization agents, especially the family and school, which can influence students' perceptions towards other ethnic groups. A study conducted by Noran Fauzan et al. (1987) found that while most parents encouraged their children to interact with other people, there is a big difference between students whose parents did not go to school and those parents who are highly educated. Johari Talib (2007) agreed that family is the most important socialization agent for children, preceding other socialization agents. Juang and Syed Moin (2010) also recognized the role of family in providing a platform for the formation of ethnic identity through ethnic socialization process. Family socialization practices have contributed to the formation of ethnic identity during childhood and adolescence.

There is no doubt that teachers and schools are also able to instill a sense of tolerance, and mutual respect among students of various ethnic identities. This influences the students when they are in higher learning institutes. According to Cushner (2008), education tries to develop cross-cultural understanding, and teach students to solve problems between cultures. Therefore, teachers can influence students' 
perspectives regarding various cultures and races. Similarly, a study conducted by Quintelier (2007) found that school can be successful in promoting tolerance among students of various ethnic groups by providing information on politics and cultures.

However, these findings differ with the findings by Mansor Mohd Noor et al. (2006) who conducted a study on three major ethnic groups of students at UUM. The study found that most students had a high sentiment of racism. Students preferred to socialize with their own kind. The researchers concluded that all this happened due to the early socialization process experienced before students enrolled in the university. Similarly, Amir Hasan Dawi (2004) also found that the students learnt about polarization as part of their campus life, apparently due to the influence of habit before they joined institutions of higher learning.

\section{Implications and Recommendations}

Considering the foregoing discussion, this study has important implications for the stakeholders, particularly the authorities of teacher training institutes. The authorities need to enhance students' interaction and maintain great cohesion among students of various backgrounds. This means that the administrators should provide support and organise activities that can foster students' interaction and cohesion. Apart from that, the management should focus on the quantity and quality of interaction between students from various ethnic backgrounds.

Among the possible initiatives that can be considered is roomsharing among students of different backgrounds. This practice is very encouraging and promising, as it enhances inter-ethnic interaction and strengthens national unity. Similarly, great efforts are needed to create a conducive environment that gives students ample opportunities to interact easily and effectively with colleagues from diverse ethnic groups. Conducive surroundings at the study areas, lounges, cafeteria, and other campus's facilities would provide ample spaces and opportunities for all students to interact with each other.

The results also showed the powerful effects of peers in influencing students to interact with friends from various backgrounds. This aspect should be emphasized in the community so that they can contribute to the ongoing interaction among students and youth of 
various ethnicities. In the long run, this will form closer and friendly relations in the plural society. Accordingly, the youth associations should enhance their efforts and activities particularly by organizing or conducting activities that may attract all s of people. Indirectly, this informal association between various ethnicities will lead to mutual understanding, honest interaction and cohesion.

Effective peer group courses should also be dconducted by youth organizations so that the younger generation would be exposed to information about ethnic diversity. This will reduce racial stereotypes and prejudice against other ethnic groups. Regional youth visits and exchange programs among young people from the peninsula, Sabah and Sarawak and Labuan should also be considered to provide opportunities for mutual understanding, information and experience about cultural diversity, values, norms and beliefs of other ethnic groups in the country. This will encourage them to be more comfortable being with people from different ethnicities without doubt and suspicion. This interaction and solidarity will eventually develop harmony in the society.

Moreover, various relevant courses on cultural diversity and ethnic relations should be conducted for the community leaders such as the tribal chiefs, village heads, and native leaders. Leaders should arm themselves with knowledge of cultural diversity to overcome racial problems, while firmly upholding the ideas of freedom, justice, equality and human values.

The results also highlighted the role of the school as a major predictor for the pattern of interaction in the institutes. This finding is consistent with many studies about how the school is able to encourage interaction and create unity. In addition to this, the Ministry of Education has introduced Native Language (Chinese, Tamil, Iban and Kadazandusun) as a new subject in mainstream schools. This step is very appealing to attract parents to send their children to mainstream schools. This will provide opportunities for students to mix and interact with friends from various ethnic groups and of course to promote cooperation among them.

It is time to set up parent support groups in schools in collaboration with the Parent Teacher Association and the National Parent Teacher Association at the school. Through parent support groups, schools will be assisted in organising activities outside the 
classrooms. Indirectly, students will gain meaningful experiences that will help them embrace diversity. They will have no problem to adapt with various kinds of people from different ethnicities as a result of being exposed to this experience through activities organized by the parents support groups.

\section{References}

Abdul Halim, R. (2009). Hubungan Kaum di Malaysia: Sejarah dan Asas Perpaduan. Shah Alam : Pusat Penerbitan Universiti.

Abdul Razaq, A., Anisa, S., Zalizan, M. J. \& Ahmad, A. S.. (2010). Kepelbagaian pelajar dan sekolah: Satu kajian kes di Negeri Pahang. Jurnal Pendidikan Malaysia 35(2) : 87-95.

Aizat, K. (2011). Konsep 1Malaysia dan cabaran pelaksanaannya ke arah pemantapan perpaduan sebuah Negara-bangsa. Sosiohumanika 4(1) : 129140 .

Amir Hasan, D. (2004). Hubungan Etnik di IPT : Satu Kajian Etnografi Habitus dan Modal Budaya di Kalangan Pelajar Berlainan Etnik, Tesis Phd Fakulti Pendidikan, Universiti Kebangsaan Malaysia.

Amir Hasan, D. (2006). Penteorian Sosiologi dan Pendidikan. Edisi ketiga. Tanjong Malim : Quantom Books.

Bronfenbrenner, U. (2005). Making Human Beings Human : Bioecological Perspectives on Human Development. Thousand Oaks, CA : Sage Publications.

Chang, M. J. (1999). Does racial diversity matter? The educational impact of racially diverse undergraduate population. Journal of College Student Development. 40(4) : 377-379.

Chang, M.J., Astin. A.W. \& Kim, D. (2004. Cross-Racial interaction among undergraduates : some consequences, causes and patterns. Research in Higher Education 45(5) : 529-553.

Chew, F. P. (2007). Sastera Melayu dan prasangka etnik : Isu-isu dan persoalan. Masalah Pendidikan 30(1) : 61-78.

Cushner, K. (2008). International Socialization of Young People ; Obstacles and Opportunities. International Journal of Intercultural Relations. Vol. $32: 164-173$.

Ezhar ,T. (2009). Contribution of interethnic contact on interethnic attitudes of Malay and Chinese-Malaysian university students in Malaysia. European Journal of Social Sciences 8(1) : 51-61. 
Faridah, K. \& Subahan, M. M. (1986). Pola interaksi kaum remaja di luar bilik darjah : satu tinjauan. Kertas kerja Konvensyen Nasional Kelima Mengenai Perpaduan. Anjuran Persatuan Pendidikan Malaysia, 15-17 November.

Fatimah, H. D. \& Abdul Hadi, Y. (2006). Polariasasi Kaum di Kalangan Pelajar-pelajar Universiti. Petaling Jaya : Pertubuhan Pembangunan Penduduk Malaysia.

Gurin, P., Dey Eric, L., Hurtado, S, \& Gurin, G. (2002). Diversity and higher education : theory and impact educational outcomes. Harvard Educational Review 72(3): 1-26.

Halualani, R. T., Anu, C., Huynh, J., Morrison, T. A., \& Dodge, P. S.. (2004). Who's interacting? and what are the talking about? intercultural contact and interaction among multicultural university students. International Journal of Intercultural Relations 28 : 353-372.

Hamidah, A. R., Norlin, A., Nor Akmar, N., Norashikin, M., Rozianah, S. \& Shah Rollah, A. W. (2011). Kajian Tinjauan Hubungan Etnik Dalam Kalangan Pelajar Tahun Satu di Kampus Johor Baharu, Universiti Teknologi Malaysia (UTM). Jurnal Teknologi. Vol. 54 : 65-76.

Johari, T. (2007). Pengaruh Gaya Keibubapaan Terhadap Pencapaian Akademik Kanak-kanak. Wacana Pengajian Umum. Siri 2 : 77-94.

Juang, L.\& Syed Moin. (2010). Family Cultural Socialization Practice and Ethnic Identity in College - Going Emerging Adults. Journal of Adolescence. Vol. 33 : 347-354.

Khalim, Z., Taib, A. \& Zulkifli, M. (2010). The effect of ethnic relation Course on the students perception towards ethnic relations among first year student of one public university in Malaysia. Pocedia Social and Behavioral Science. Vol. 2 : 3596-3599.

Kementerian Pelajaran Malaysia. (2012). Laporan Awal Pelan Pembangunan Pendidikan 2013-2025. Putrajaya: Kementerian Pelajaran Malaysia

Kim, Y. K. \& Sax, L. J. (2007). Different patterns of student - faculty interaction in research universities : An analysis by student gender, race, SES, and first-generation status. Research \& Occacional Paper Series. Center of Studies Higher Education, University of California.

Mohd Rizal, M. S. \& Thay, C. Y. (2012). Tahap hubungan etnik: kajian di kalangan pelajar yang mengikuti kursus Sarjana Muda Teknologi Serta Pendidikan (Kemahiran Hidup), sesi pengajian 2007-2008, semester 2 di Universiti Teknologi Malaysia, Skudai. Journal of Technical, Vocational \& Engineering Education 6 : 59-72.

Mansor, M. N., Abdul Rahman, A. A. \& Mohamad, A. I. L. (2006). Hubungan Etnik di Malaysia. Petaling Jaya: Prentice Hall. 
Najeemah, M. Y. \& Yasmin, A. (2010). Bahasa dan sempadan etnik dalam kalangan murid pelbagai etnik di sekolah menengah di Malaysia. Kertas Kerja Persidangan Antarabangsa Minoriti dan Majoriti: Bahasa, Budaya dan Identiti, 23-24 November. Kuching, Malaysia.

Noran Fauzan, Y., The, Y. K. \& Salma, I. 1987. Faktor-faktor yang Berkaitan dengan Perhubungan Kaum-Kes UUM. Kertas Kerja Seminar Kebangsaan Mengenai Perpaduan Nasional. Anjuran Universiti Utara Malaysia, 26-28 Mac.

Quintelier, E. (2007). European Citizenship and Ethnic tolerance Among adolescent: Result of a Representative Survey Among Belgian 16 Year olds. Paper presented at European Sociological Association: Youth Globalization and Migration Local Diversity in Transition, Smolenice, Republik Slovania, 19-22 Januari.

Ramlee, M., Norzaini, A., Faridah, K., Abdul Razak, A. \& Maimun, A. L.. 2009. A Survey of Social Interaction Among Diverse Students in Malaysian Higher Learning Institutions. International Journal of Learner Diversity. Vol. 1 : 93-112.

Rodrigues-Garcia, J.M \& Wagner, U. (2009). Learning to be prejudiced : a test on unidirectional and bidirectional models of parents-offspring socialization. International Journal of Intercultural Relations, 33 : 516523.

Rusimah, S., Mohd Ainuddin, I. L. A. \& Salma, I. 2004. Kajian hubungan kaum di kalangan pelajar Sekolah Pembangunan Sosial Universiti Utara Malaysia. Kertas Kerja Seminar Antarabangsa Nilai dalam Komuniti Pasca Modernisme, 4-6 September.

Seltzer, V \& Waterman, R. (1996). A cross national study of adolescent over concordance on issue of the future. Journal of Adolescent Research 88(1) : 461-482.

Shamsul Amri, B. (2007). Modul Hubungan Etnik. Shah Alam : Pusat Penerbitan Universiti, Universiti Teknologi Mara.

Umbach, P.D. \& Kuh, G.D. (2006). Student experiences with diversity at liberal arts college : another claim for distinctiveness. The Journal of Higher Education 77 (1) : 169-192. 